contamination, assuming that there is a sufficient covering of impervious strata and that the outcrop lies in an area where only pure rain water is collected.

The engineering works required for obtaining water from water-bearing strata may be divided into three sections, the first being small borings, such as those required for the supply of small quantities to country houses, medium size factories, etc.; the second section would comprise large borings, such as those required for public water supply undertakings or large manufacturing works; and the third section would consist of large wells, with headings or galleries, such as those required for the supply of large towns and cities. Borings under the first eategory would be capable of delivering water at the rate of about 100,000 gallons in twenty-four hours, those in the second category at the rate of about two million gallons in twenty-four hours, and those in the third category at a rate exceeding five million gallons in twenty-four hours. The first and second classes have many points in common, the principal difference being that the plants and apparatus required in the second case are considerably larger and heavier. The paper then went on to describe the procedure of making the borings and sinking the lining tubes.

In the course of his paper, Col. Restler mentioned that water derived from an underground source is, in very cold weather, many degrees higher in temperature than water derived from a river source, and that it is quite noticeable that the former does not freeze in mains or service pipes so soon as river water. This is a point of practical importance, because when very cold water is being transmitted through mains, it frequently produces a local contraction in the metal and causes cast iron pipes to fracture.

\section{Post-Glacial Research in Ireland}

$I^{\mathrm{T}}$ has been evident for many years that a large number of the special problems of plant and animal distribution in Ireland could only be solved if it were possible to obtain trustworthy evidence as to the major post-glacial changes in the Irish fauna and flora. Accordingly a committee was formed in 1933, with the object of promoting detailed investigations of representative glacial and post-glacial deposits and, particularly, of enlisting the method of pollen analysis in the detailed study of the problem. The work and aims of the eommittee up to the end of 1934 are summarised by various authors in the November number of the Irish Naturalist (5, 125 ; 1934). Active field work was commenced in 1934, so that full details of the results are not yet available. The particular feature of the work was, however, that the sites examined were chosen because they included definite and representative archæological horizons in various parts of the country.

An outline of the broad results of the pollen analyses of peats is given by Prof. Knud Jessen, and this indicates the main features of the work attempted. From results on the deeper bogs examined, the tentative suggestion is made that there was an increase in moisture in the later part of the Bronze Age, which occasioned wide-spread replacement of forest by peat bog. If, as is possible, this change corresponds in time with the sub-boreal to sub-Atlantic climatic change so well known on the Continent, the late Bronze Age in Ireland should synchronise with the beginning of the Iron Age (Halstatt period) in Europe. Before this transition, Ireland was forest clad to the western coasts and high up the mountains. Since then, forests have disappeared from western Ireland.

Investigations carried out in Northern Ireland were devised to secure, if possible, chronological comparisons between the raised beaches and the development of inland bogs containing Stone Age culture layers. The results will be awaited with interest, as will those from the Lough Neagh area, where the discovery of fossil Naias flexilis fruits may throw light on the origin of the American element in the Irish flora. The late glacial deposits of the Ballybetagh bogs, the classical site for remains of the Irish 'elk', yielded a collection of northern or highland types of plants apparently of a date prior to the post-glacial birch epoch.

\section{University and Educational Intelligence}

Cambridge.-Mr. K. W. M. Pickthorn, fellow and tutor of Corpus Christi College, has been returned unopposed as National Conservative member of Parliament for the University. His was the only nomination for the seat vacant by the resignation of Mr. G. H. A. Wilson (Conservative), Master of Clare College, who is to be the next vice-chancellor of the University.

London.-The Senate, at its meeting on February 21, approved a proposal to hold external examinations of the University in New York. This proposal, which is an entirely new departure in the history of the University, was submitted by His Excellency the American Ambassador and the British Foreign Office to the State Department in New York, which has given its formal sanction. These examinations are to be available for both British subjects and students of other nationalities.

The Court has accepted the offer by the Radeliffe Trustees of the Radcliffe 24-in. refracting telescope, which was the main instrument of the Radcliffe Observatory in Oxford and has now been rendered available by the removal of this Observatory to South Africa. It is hoped, so soon as funds can be obtained by the University for this purpose, to re-erect the Radcliffe telescope on the site of the present University of London Observatory in Mill Hill Park, where the Wilson 24-in. reflector and the Fry 8-in. refractor, as well as other instruments, are already housed.

Applications are invited for Lady Tata Memorial Research Scholarships in medicine, of $£ 400$ a year each, for research work in diseases of the blood with special reference to the leukæmias. These scholarships are renewable annually up to a normal maximum of three years, and there are likely to be at least two vacancies for new candidates ready to begin work in October 1935. The scholarships are open to suitably qualified men or women of any nationality, and are ordinarily awarded on a whole-time basis. Applications must be made by April 15. Further particulars and forms of application may be obtained from the Secretary, Scientific Advisory Committee, 138 Bedford Court Mansions, London, W.C.1.

AMERICAN university statistics are exhibited and interpreted in an article by Dr. Walters, president of the University of Cincinnati, in School and Society of December 15. The outstanding feature of the returns is the reversal of the tide of enrolment, which has been ebbing since 1930. This recovery, which is much greater in institutions under public control than in 
others, and is most pronounced in the mountain and south central States and least in New England and middle Atlantic States, is attributed to the following influences: financial aid for students from the Federal Emergency Relief Administration, the difficulty of finding employment for young people leaving school, improved economic conditions in some parts of the country and the persistent faith of parents in the value of higher education. 'Liberal arts' continues to be the most popular choice of entering students, although its percentage (72) of the total entries was slightly lower in 1934 than in the preceding year. Some striking increases in the entries into the various professional schools were : 48 per cent in agriculture, 27.5 per cent in commerce and business administration and 20.5 per cent in engineering. Another statistical article in the same issue directs attention to the fact that one tenth of the expenditure of Yale University last year was on assistance to students in need of financial aid.

\section{Science News a Century Ago}

\section{Resumption of Work on the Thames Tunnel}

The construction of Brunel's tunnel beneath the Thames from Rotherhithe to Wapping began in 1825 , had been brought to a premature close in 1828 , and for nearly seven years work was at a standstill. In 1834, however, a "Tunnel Club" was formed, principally by fellows of the Royal Society, and successful efforts were made to secure assistance from the Government for the completion of the tunnel. At a meeting of the shareholders held on March 3, 1835, in the City of London Tavern, the chairman announced that $£ 247,000$ in exchequer bills was to be advanced on the security of the property. $\mathrm{He}$ said that "the Company were much indebted to the late Government, as well indeed as to the present, for this aid. Great credit was due to all those who had advocated the grant of money, and among those who had formed the deputation to the Government were men of all parties. It had indeed, been the wish of all persons, at home and abroad, that this splendid work should be completed, and foreigners considered. it a national disgrace that it should have been allowed to remain seven years without an attempt being made to complete it. The time, however, was not far distant when it was confidently believed this magnificent work would be completed." At the same meeting, Brunel made a report in which he said that on February 4 "the water-ways, which had been closed for several years were reopened, as a preparatory step for entering the shield. It was quite satisfactory to find that the infiltrations are very inconsiderable, and are just the same as they were before". The tunnel was opened to the public on March 25, 1843.

\section{Bessel's New Method of Lunar Distances}

An advertisement in The Times of March 8, 1835, announced: "This day is published, 8vo., 5s., Bessel's New Method of Lunar DistancesDistances of the Sun and the four planets Venus, Mars, Jupiter and Saturn, from the Moon, calculated according to Mr. Bessel's method, together with their places for every day in the year 1835; to which is added, an Ephemeris of the Moon calculated for every third hour of mean Greenwich time upon M. Damoiseau's Tables; the culmination of the Moon for every day in 1835 for the Altona meridian, with the auxiliary quantities to reduce it to other meridians; and Tables for finding the Latitude by the Pole Star for 1835, calculated under the direction of H. C. Schumacher. John Murray, Albemarle St."

\section{Sir Robert Peel and Mrs. Somerville}

After offering a Civil List Pension to Airy, Sir Robert Peel wrote in Mareh 1835 to Mrs. Somerville, saying, "In advising the Crown in respect of civil pensions, I have acted equally with a sense of public duty and on the impulse of my own private feelings in recognising among the first claims on the Royal favour those which are deserved from eminence in science and literature. . . . In reviewing such claims, it is impossible that I can overlook those which you have established by the successful prosecution of studies of the highest order, both from the importance of the objects to which they relate, and from the faculties and acquirements which they demand. . . . I am enabled to advise His Majesty to grant to you a pension on the civil list of two hundred pounds per annum; and if that provision will enable you to pursue your labours with less of anxiety, either as to the present or the future, I shall only be fulfilling a public duty, and not imposing upon you the slightest obligation, by availing myself of your permission to submit such a recommendation to the King". The pension was conferred on Mrs. Somerville and later, when Lord John Russell was Prime Minister, it was increased to $£ 300$ a year.

\section{Death of Thomas Drummond}

Early in March 1835, Thomas Drummond, the botanical collector, died at Havana, after spending ten years collecting in North America. The younger brother of James Drummond (1784 ?-1863) who investigated the botany of Western Australia, Thomas Drummond began life as a nurseryman in Forfar, but became known to botanists by distributing sets of mosses. In 1825 he was selected as assistant naturalist to Dr. (afterwards Sir John) Richardson in Sir John Franklin's second land expedition in connexion with the discovery of a North-West Passage. $\mathrm{He}$ accompanied the expedition westward by the Hudson and Lakes Ontario and Winnipeg to the Mackenzie River, but quitted the main party at the Rocky Mountains. His subsequent botanical expeditions took him on foot across the Allegheny Mountains to St. Louis, to New Orleans and to Texas. At Velasco he was attacked by cholera but was afterwards able to continue his excursions. $\mathrm{He}$ finally embarked for Havana on February 9, 1835. The plants he sent home were deseribed by Sir William Hooker in his "Flora Boreali Americana", his "Journal of Botany" and in the "Companion to the Botanical Magazine".

\section{Objects for the Microscope}

In the Records of General Science of March 1835 under the heading "Scientific Intelligence", it is stated that "Mr. Andrew Pritchard, Pickett Street, Strand, has just published a useful little work for such persons as take an interest in examining the beauties of the minute works of nature. It consists of a list of 2000 microscopic objects, and is intended to serve as a guide for selecting and labelling subjects of natural history, botany and mineralogy. Some good observations are prefixed in reference to mounting microscopical subjects, with remarks on the circulation of animals and plants." 